\title{
The impact of the UN Special Procedures on the development and implementation of economic, social and cultural rights
}

\author{
by Christophe Golay, Claire Mahon and Ioana Cismas*
}

[Article to be published in the International Journal of Human Rights, Vol. 15, No. 2, 2011]

\begin{abstract}
This article analyses the impact that some of the United Nations special procedures, namely those focusing on economic social and cultural rights (ESC rights), have upon the development of international human rights law, in particular through clarifying the normative content of the rights and the development of soft-law instruments. It also examines the impact of the ESC rights mandate-holders in implementing ESC rights through promotion activities, protection work and country missions and explores modalities for improvement.
\end{abstract}

Keywords: UN special procedures; special rapporteurs; independent experts; economic, social and cultural rights; promotion; protection; communications; country missions; Human Rights Council

\footnotetext{
* Dr Christophe Golay and Ms Claire Mahon are the joint coordinators of the Project on Economic, Social and Cultural Rights at the Geneva Academy of International Humanitarian Law and Human Rights. They worked for several years as advisors to Jean Ziegler, the special rapporteur on the right to food, 2000 - 2008. Ms Ioana Cismas is a PhD candidate at the Graduate Institute of International and Development Studies and a researcher with the Project on Economic, Social and Cultural Rights. Contact email: escrproject@adh-geneve.ch.
} 


\section{Introduction}

The United Nations (UN) member States were slow to develop thematic special procedures addressing economic, social and cultural rights (ESC rights) comparative to their willingness to embrace procedures focusing on civil and political rights ( $\mathrm{CP}$ rights). The former Commission on Human Rights created the Working Group on Enforced or Involuntary Disappearances in 1980, while the first special rapporteur on an ESC right - the right to education - was not appointed until 1998. ${ }^{1}$ Nonetheless, this timid start gave way to the mushrooming and flourishing of special procedures charged with ESC rights mandates in the late $1990 \mathrm{~s}$ and in the $2000 \mathrm{~s}^{2}$

At present, out of the thirty-one thematic special procedures of the Human Rights Council, eight deal specifically with ESC rights and related issues. In the order of their date of establishment, these are: the Special Rapporteur on the right to education (1998), the Independent Expert on the question of human rights and extreme poverty (1998), ${ }^{3}$ the Special Rapporteur on adequate housing as a component of the right to an adequate standard of living and on the right to non-discrimination in this context (2000), ${ }^{4}$ the Special Rapporteur on the right to food (2000), the Independent Expert on the effects of foreign debt and other related international financial obligations of States on the full enjoyment of human rights, particularly economic, social and cultural rights (2000), ${ }^{5}$ the Special Rapporteur on the right of everyone to the enjoyment of the highest attainable standard of physical and mental health $(2002),{ }^{6}$ the Independent Expert on the issue of human rights obligations related to access to safe drinking water and sanitation (2008), ${ }^{7}$ and the Independent Expert in the field of cultural rights (2009). Some others, such as the Special Rapporteur on the situation of human rights and fundamental freedoms of indigenous people, the Special Representative of the Secretary-General on the issue of human rights and transnational corporations and other business enterprises, and the Special Representative of the Secretary-General on human rights defenders, have a crosscutting mandate which certainly involves a treatment of ESC rights. Further, although an analysis of the work of the country-specific special rapporteurs is not included in this study, it should be noted that experts charged with geographic mandates have also at times taken up ESC rights in their examination of the human rights situation of specific countries, however, these rights have generally not been addressed by the country-specific mandate holders to the same extent as CP rights. ${ }^{8}$

Despite the increase in number and in importance of special procedures focusing on ESC rights since 1998, little analytical attention has been given to the impact of these particular human rights mechanisms. Some publications tackle the relevance of special procedures $^{9}$ although few touch upon the impact on the ground and the normative development ensuing from the work of ESC rights special rapporteurs and independent experts. In general, a gap in human rights literature can be observed, particularly regarding the functions and functioning of ESC rights special procedures. Against this background, the current article addresses the opportunities and deficiencies of ESC rights special procedures in an attempt to fill this theoretical void. ${ }^{10}$ It is also hoped that the conclusions of this study may be of significant practical relevance to the future work of these human rights mechanisms.

In terms of structure, the article is divided in two parts. The first part analyses the impact of the ESC rights special procedures on the development of international human rights law. The second part is divided in three sub-sections and focuses on the impact of the ESC rights special procedures on the implementation of ESC rights, through: promotion activities, protection work and country missions. 


\section{The impact of economic, social and cultural rights special procedures on the development of human rights law}

Despite the significant progress made in repositioning ESC rights on the same value plane as civil and political rights, challenges remain. As part of the lack of justiciability argument charged against ESC rights, it has often been proposed that the content of ESC rights is not sufficiently normatively developed and lacks the necessary clarity to even allow monitoring, let alone to be adjudicated in courts. The following section of this article will address the achievements of ESC special procedures in the field of normative development, specifically in defining the content of different ESC rights and the corresponding States' obligations, as well as in developing international standards and other soft law documents so as to respond to challenges posed by the implementation of these rights in current times.

\section{Defining the normative content of economic, social and cultural rights and correlative States' obligations}

There is a general pattern in the work of ESC rights mandate-holders in as much as they attempt to underline and tackle the structural issues which lie at the basis of ESC rights violations. This holistic approach is evident also in the way in which they interpret and develop international law. In their thematic reports, several special rapporteurs and independent experts sought to fill normative gaps by developing analytical frameworks or clarifying aspects of a certain human right, including the specific application to particular groups such as women, children, indigenous people, prisoners, and people with disabilities.

For example, Katarina Tomasevski, the first Special Rapporteur on the right to education, developed in her early reports to the Commission on Human Rights the '4As' scheme in respect to the right to education, ${ }^{11}$ according to which 'governments are obliged to make education available, accessible, acceptable and adaptable'. ${ }^{12}$ In Tomasevski's model, availability embodies two different type of obligations: the negative obligation of the State to permit the creation of schools, and the positive obligation to ensure that free and compulsory education is available to all school-age children. Governments are obliged to assure access for children to primary education free of charge. Secondary and higher education may entail tuition fees, however States are under the obligation to progressively facilitate access to postcompulsory education as circumstances permit. Acceptability involves, inter alia, a guaranteed quality of education, to be achieved, for example through establishing, monitoring and enforcing a set of criteria for teachers, ensuring minimum standards of health and safety, and providing special attention to the needs of minorities and indigenous people. Adaptability in the realm of education means that schools and the school system must adapt to the needs and rights of the children, as sanctioned, amongst others, by the Convention on the Rights of the Child. $^{13}$

Because of its attributes of comprehensiveness, coherence and indeed commonsense, the '4As' scheme revolutionized the understanding of the content of ESC rights and their practical implementation. It has since been adopted, adapted and expanded upon by the Committee on ESC Rights in defining the right to education and other rights, ${ }^{14}$ and by several other special rapporteurs in the context of various ESC rights. ${ }^{15}$ The '4As' framework cannot and was not intended to be applied ad litteram to every ESC right; it offers however a model of how the content of an ESC right can be clarified with clear implications for the monitoring and adjudication of the State's obligations.

One of the most recent examples of normative development as a result of the work of an ESC rights mandate holder is to be found in the area of sanitation. Although today much of the developing world is confronted with a ravaging sanitation crisis, ${ }^{16}$ the human rights 
aspects of sanitation and the legal obligations of States in this respect remain little explored and thus the legal system of protection of individuals and groups underdeveloped. ${ }^{17}$ In this context, Catarina de Albuquerque, the Independent Expert on water and sanitation, embarked in her 2009 report to the Human Rights Council on a project to define sanitation from a human rights perspective, to clarify what obligations Governments carry under human rights law in respect to sanitation and interestingly what obligations they do not have. ${ }^{18}$

The 'working definition of sanitation in human rights terms' refers to 'a system for the collection, transport, treatment and disposal or reuse of human excreta and associated hygiene.' ${ }^{19}$ According to the Independent Expert, States are under a legal obligation to ensure without discrimination that everyone has physical and economic access to sanitation, in all spheres of life, which is safe, hygienic, secure, socially and culturally acceptable, provides privacy and ensures dignity. De Albuquerque argues that the existence of certain obligations of States in respect to sanitation is undisputed, not least of all because of the inextricable link between sanitation and the realization of many other rights. ${ }^{20}$ Like many other mandateholders and the Committee on ESC rights, Catarina de Albuquerque uses the respect-protectfulfill framework in respect to the States' obligation vis-à-vis sanitation. ${ }^{21}$

It is evident from her 2009 report that de Albuquerque understands her mandate as Independent Expert to include the development of the law on the issue of sanitation. Moreover, it appears that she sees a role for the special procedures to act as a source of correct information and indeed education in their specific field. Therefore, in her report she rebuts certain myths, which strongly contributed to the perception that sanitation in particular, and ESC rights in general, are too costly and too intrusive in the internal affairs of a State. Based on these myths, an infamous discourse has been constructed which equated ESC rights with policy goals, as opposed to progressively realizable rights, whose minimum standards and the requirement to not discriminate indeed raise immediately realizable duties for governments. To exemplify this, the report rightly highlights the misperceptions that States may be obliged to construct individual toilets in every home. In fact, as de Albuquerque shows, context specific analysis is primordial in human rights law implementation and specifically in the case of sanitation in which an enabling environment - including access to information and education - is essential in order for individuals and communities to understand the benefits of sanitation and hygiene. ${ }^{22}$ It may be said that the 2010 resolutions of the UN General Assembly and Human Rights Council affirming that the right to safe drinking water and sanitation as a human right are the fruit of the clarification process undertaken by the Independent Expert. ${ }^{23}$

Further examples of normative development through the work of special rapporteurs can be found in the areas of extraterritorial obligations and international cooperation and assistance, two aspects of particular importance for the implementation of ESC rights, which were addressed by Jean Ziegler, the first Special Rapporteur on the right to food and Paul Hunt, the first Special Rapporteur on the right to health. In his 2005 report to the Commission on Human Rights, Jean Ziegler placed the need for clarifying the extraterritorial obligations of States in respect to the right to food in the context of an increasingly integrated world economy, in which trade decisions by one country affect others and thus the latter's capacity to fulfil its own human rights obligations. ${ }^{24}$ After identifying the legal basis for extraterritorial obligations in the provisions of the Universal Declaration of Human Rights, International Covenant on Economic, Social and Cultural Rights and the Convention on the Rights of the Child, the Special Rapporteur presented a typology of the extraterritorial obligations linked to the duties to respect, protect, and support the fulfillment of the right to food. As the report states, the 'objective [is not] to suggest that extraterritorial obligations in relation to the right to food are justiciable, but to show that States have responsibilities under international law towards people living in other countries, both through their own actions and through their 
decisions taken as members of international organizations. ${ }^{, 25}$ Olivier the Schutter, the current Special Rapporteur on the right to food, who started his mandate in May 2008, made further suggestions for better integrating a human rights approach to development cooperation and food aid. His framework envisages three levels at which the realization of the right to food must be seen as the yardstick for cooperation and aid: the normative level, i.e. the obligation to provide cooperation; the level of implementation via tools such as national strategies and 'disciplined and context-specific' food aid; and at the level of evaluation. ${ }^{26}$

In his 2008 report on his mission to Sweden, Paul Hunt clarifies 'the contours and content of the human rights responsibility of international assistance and cooperation in health', a crucial issue since, as the Rapporteur acknowledges, in practice the realization of the right to the highest attainable standard of health, especially in developing countries, is highly dependent upon international cooperation and assistance. ${ }^{27}$ First, the Special Rapporteur establishes that the legal duty of a State to dispose of its available resources through offering international assistance and cooperation is a responsibility supplementary to a State's own obligation to realize the right to health within its own available resources. Second, the report identifies some key right-to-health features of a substantive and procedural nature, which international assistance and cooperation should support, including: freedoms and entitlements, equality and non-discrimination, participation, monitoring and accountability. Third, the report details the respect-protect-fulfill framework in the context of the human rights responsibility of international assistance and cooperation. The last element put forward by Paul Hunt, which has been underlined in the context of earlier reports, ${ }^{28}$ refers to policy coherence across national and international policymaking processes. ${ }^{29}$

Prescribing to a State what and how it should internationally cooperate or assist others is clearly a sensitive task. What the work of the Special Rapporteurs in this area shows, however, is that the procedural and substantive requirements put forward by human rights law are not a collection of non-implementable prescriptions. On the contrary, Ziegler and Hunt point to the fact that in addition to contributing to the realization of particular rights, implementing these frameworks will contribute to increased effectiveness in the realization of specific rights - not least of all through empowering disadvantaged and marginalized people and communities - and increased accountability of the donor and receipient States.

Finally, it is important to mention the efforts of special procedures in addressing the applicability of ESC rights, in particular in relation to vulnerable, disadvantaged or marginal individuals and groups. Amongst others, the Special Rapporteur on the right to education, Venor Muñoz Villalobos, focused on the education of girls, ${ }^{30}$ of persons with disabilities, ${ }^{31}$ and of persons in detention, ${ }^{32}$ and the ensuing States' obligations. The first Special Rapporteur on the right to food also focused in his reports on developing the legal framework of the right to food of women, ${ }^{33}$ children, ${ }^{34}$ and indigenous people, ${ }^{35}$ and the first Special Rapporteur on the right to housing focused on the right to housing of women, ${ }^{36}$ and dedicated his 2005 annual report to homeless individuals and homelessness. ${ }^{37}$

These are but some of the examples of the way in which the special procedures have drawn up the broad frameworks for establishing normative content for the rights, either through the '4As' framework or context-specific understandings of particular rights. In addition to helping advance understanding of cross-cutting aspects such as extra-territorial obligations and international cooperation and assistance, the ESC rights special procedures have worked to establish the frameworks for focusing attention on marginalized groups. Each of these examples, plus the myriad of other cases not highlighted here, contribute to demonstrating the important role that the ESC rights special procedures have played in progressing our understanding about the normative content of these rights and thus the overall human rights law framework. 
Many ESC rights mandate-holders have also played a key role in the development of new international human rights standards intended to cover aspects or areas in need of legal regulation or further clarification. The involvement of the special procedures differs according to the type of process that led to the development or adoption of these instruments.

The Voluntary Guidelines to support the progressive realization of the right to adequate food in the context of national food security ${ }^{38}$ adopted by consensus by the member States of the UN Food and Agriculture Organization (FAO) in November 2004 represent an example of an instrument drafted by States with the contribution of special procedures. While the drafting process was State-led, the Special Rapporteur on the right to food managed to shape the initial stages of negotiations through leveraging expertise on the right to food in a setting dominated by governmental specialists on agriculture. In later stages of the negotiations, the Special Rapporteur expressed his support for proposals made by civil society organizations and States with a more progressive position on the issue of the right to food, and this further influenced the negotiations, lending legitimacy to these proposals and positions. $^{39}$

Other such soft-law instruments have developed as a result of drafting processes led by the special procedures themselves, accompanied by extensive consultations over the years including with States and other stakeholders. Two such examples are the Draft General Guidelines on Foreign Debt and Human Rights ${ }^{40}$ and the Draft Guiding Principles on Extreme Poverty and Human Rights: The Rights of the Poor. ${ }^{41}$ Inevitably, given the sensitivity of the topics and the diversity of actors affected by the outcome, the respective Independent Experts charged with the drafting process faced and continue to encounter a number of challenges. There is some reluctance from the principle actors, States, and the private sector, also addressed by both Guidelines, to accept the need for regulation. Moreover, international financial institutions tend to object to having their actions regulated by such guidelines, and they thus challenge the applicability of such instruments. Lastly, it has proven difficult to balance a desire to ensure the participation of all interested actors and the need to urgently complete the Guidelines so as to produce a useable tool for two fields that are in dire need of regulation.

Arguably more successfully, the first Special Rapporteur on the right to health led a process of consultations with the private sector and NGOs for the drafting of the Human Rights Guidelines for Pharmaceutical Companies in relation to Access to Medicines. ${ }^{42}$ The Guidelines address, inter alia, the following: disadvantaged individuals and groups; transparency; monitoring and accountability; public policy influence, advocacy and lobbying; quality; patents and licensing; pricing; ethical marketing. While some pharmaceutical companies and some States supported the drafting process and were in favor of the instrument, other companies refuted the application of the Guidelines. GlaxoSmithKline, for example, expressed concern that the right to health is 'not well defined' for non-state actors, and exposed the view that the company could thus not be held legally accountable under international human rights law. ${ }^{43}$ As noted in an editorial in The Lancet, a prestigious health journal, the success of the Guidelines however lays precisely in the way they sought to clarify the applicability of the right to health for non-state actors by moving away from lofty phrases to focusing instead on precise, specific and operational requirements under international human rights law. ${ }^{44}$

An earlier example of such an interpretive instrument is the Basic Principles and Guidelines on Development-based Evictions and Displacement, drafted by the first Special Rapporteur on the right to adequate housing. The Basic Principles and Guidelines were developed in close cooperation with civil society organizations to address certain operational 
aspects that were not sufficiently covered by the Committee on ESC Rights' General Comment No. 7 on forced evictions. ${ }^{45}$ The objective was to offer a step-by-step approach that States could follow, to ensure that the so-called necessary displacements and evictions due to development were conducted in compliance with human rights law. The then-Special Rapporteur on the right to adequate housing, Miloon Kothari sought to legitimize his decision not to subject the drafting process to the review of the Human Rights Council (and rather presented a final version of the Basic Principles and Guidelines as an annexure to his 2007 report) by arguing that he was merely giving an interpretation of existing law.

Large-scale acquisitions and leases: A set of core principles and measures to address the human rights challenge drafted by Olivier de Schutter have also been presented as an interpretive instrument reflective of existing law articulated by the Special Rapporteur on the right to food so as to set criteria for the phenomenon that has become to be known as 'landgrabbing, ${ }^{46}$.

Many of the international standards developed by, or with contributions from the ESC rights special procedures have had a considerable impact on the development and implementation of international law in the their field. Several of the instruments are regularly quoted by UN treaty bodies ${ }^{47}$ and used by regional adjudication bodies or in national court cases. ${ }^{48}$ Many are extensively used for monitoring purposes on the ground by civil society organizations and UN agencies, ${ }^{49}$ or to assist in the implementation of ESC rights and evaluation of progress by governments. ${ }^{50}$

\section{The impact of the economic, social and cultural rights special procedures on the implementation of economic, social and cultural rights}

Special procedures, regardless of whether they have geographical or thematic mandates or whether the latter focus on CP or ESC rights, share a toolbox of similar methods to improve the implementation of human rights, and several typologies have been put forward to map these methods. For example, a background paper by the Office of the High Commissioner for Human Rights (OHCHR) lists the following activities in which most special procedures generally engage in: country visits or fact-finding missions; sending communications to governments; preparing thematic studies; recommending programs of technical cooperation; and interacting with the media. ${ }^{51}$ For the purpose of this current analysis of the impact of the ESC rights special procedures on the implementation of ESC rights, we will focus on their activities in the area of promotion and protection of ESC rights respectively and their country missions, through offering concrete examples.

\section{Promoting economic, social and cultural rights}

Mandate-holders have been effective in promoting ESC rights in different contexts and to different audiences including States, UN agencies, and civil society organizations. Many ESC rights special procedures have been advocating for a human rights-based approach to development or emerging issues, such as climate change, or for the application of ESC rights during armed conflicts and emergency situations. At the same time, they have developed new ways of promoting ESC rights to vast audiences, through the use of new technologies such as websites, blogs, movies and more traditional publications.

The work of the first Special Rapporteur on the right to adequate housing with UN Habitat, governments and NGOs on a rights-based approach to evictions and displacement is an example of how development can be effectively framed in human rights terms. 
Development thus understood improves the lives of many without excluding the disadvantaged and marginalized. Miloon Kothari was very active in promoting the use of human rights impact assessments to empower vulnerable populations while not hindering development, through focusing on sustainability. Likewise, the first Special Rapporteur on the right to health worked with the World Health Organization to infuse a right-to-health spirit into the development activities of the lead UN health agency. Similarly, both the first and current Special Rapporteurs on the right to food have been actively engaged with the FAO and several governments on development issues. All these attempts on the part of the ESC rights special procedures to work together with major donors and international organizations were and are targeted towards achieving a shift in paradigm: development without human rights can simply not be sustainable.

Several initiatives of the UN special procedures are relevant in the context of the pressure posed by climate change on ESC rights. Raquel Rolnik, the current Special Rapporteur on the right to adequate housing, focused in her 2009 report to the General Assembly on the consequences of climate change on the realization of the right to housing and considered policies on mitigation and adaptation from a human rights perspective. ${ }^{52}$ As she highlights in her report, the Basic Principles and Guidelines on Development-based Evictions and Displacement developed by her predecessor can be of great utility in the context of displacement due to climate change. Also of note in relation to the contribution of the special procedures to the climate change issue is the publication by Jean Ziegler and the Secretariat of the UN Convention to Combat Desertification on the right to food and desertification, ${ }^{53}$ as well as the declaration by Olivier de Schutter prior to the Copenhagen Summit on climate change urging States to root climate change policies in human rights principles. ${ }^{54}$ These are examples of how special procedures can produce influential pieces of work beyond their annual reports or the drafting of soft-law instruments, which nonetheless can play an important role in shaping the debate on particular emerging issues of global concern.

Another issue of note is the global food crisis, which reached its peak in 2008 and contributed to a staggering number of more than 1 billion people being undernourished worldwide. This was thoroughly addressed by both the first and current Special Rapporteurs on the right to food in reports to the Human Rights Council, ${ }^{55}$ in public statements, interventions and other reports. ${ }^{56}$ Among the key achievements of Olivier de Schutter's efforts is the recognition by stakeholders of the need to base the response to the food crisis on the human right to food.57

Finally, various special procedures have focused on ESC rights during armed conflict in an attempt to clarify States' obligations and the relationship between human rights and humanitarian law during such times. The right to housing in armed conflict situations has been dealt with by the report of Miloon Kothari on his mission to the Occupied Palestinian Territories. ${ }^{58}$ The right to education in times of armed conflict and emergency situation was discussed by Special Rapporteur Vernor Muñoz Villalobos in his 2008 thematic report focusing on this issue. ${ }^{59}$ The right to food in armed conflict situations has been dealt with by a thematic report of Jean Ziegler ${ }^{60}$ and by his reports on his missions to the Occupied Palestinian Territories ${ }^{61}$ and Lebanon. ${ }^{62}$ To exemplify the importance and legitimacy of special procedures addressing ESC rights in armed conflict situation we can recall for instance that the International Court of Justice made use of the information from the country report on the Occupied Palestinian Territories of the Special Rapporteur on the right to food in its Advisory Opinion on the Legal Consequences of the Construction of a Wall. ${ }^{63}$

\section{Protection of economic, social and cultural rights}


Beyond concepts and theories, the ultimate value of ESC rights, and indeed of human rights in general, lays in their practical application to real cases and in protecting the lives of real people. Special procedures have made diverse attempts to make their analytical work practical and show how to apply the frameworks they have developed to protect victims of human rights violations on the ground. Some of the main methods used by mandate-holders are the communications to governments and other stakeholders and publicity and media work.

\section{Communications}

In fulfilling their role of protecting individuals and groups from violations of human rights, special procedures receive communications on violations which have occurred, are ongoing, or which are of high risk of occurring, and subsequently seek to intervene with the relevant governments and other actors about such violations. While raising a communication on a human rights issue with a special procedure should not be accompanied by any expectation that it will be adjudicated with the binding force of a judicial decision, the communications procedure nonetheless carries a number of attributes which makes it an extraordinary service for victims of human rights abuses, including of ESC rights violations. For a communication to be submitted there is no obligation to exhaust the domestic remedies, a non-requirement which is pivotal to the protection process in over-charged or corrupt judicial systems or in urgent situations. A communication can be submitted by the victim or by third parties, including NGOs, 'claiming to have direct or reliable knowledge of those violations substantiated by clear information. ${ }^{, 64}$ Follow up communications from the special procedures to governments are initially confidential until the summary of the letters and the received replies are made public as addenda to the special procedures' annual reports.

Recent trends show that ESC rights mandate-holders have received an increasing number of communications. Between thirty to sixty of these, per year and per mandate, have been sent to governments. On average, $30 \%$ of the communications forwarded to governments or other duty-bearer receive a response. In this context, individual and joint communications, including with CP mandates, have proven to be effective. Among the ESC rights special procedures, the largest number of communications are sent by the Special Rapporteurs on the right to food and the right to adequate housing, respectively, and the majority of the latter concern forced evictions.

Communications can be classified according to their ultimate addressee and their type. ESC rights mandate-holders have forwarded communications to both States and non-State dutybearers, including international organizations and transnational corporations. It has become common practice for the special procedures to submit urgent appeals in cases where the alleged violations 'are time-sensitive in terms of involving loss of life, life-threatening situations or either imminent or ongoing damage of a very grave nature to victims' ${ }^{65}$

Communications to States can take several forms, such as letters of concern, letters of allegation or urgent appeals. Ultimately, the aim of these letters sent by the special procedures is to create a dialogue with the respective State. In the absence of 'teeth', forging a dialogue with the State is a prerequisite for preventing abuse, finding redress or compensating a victim of a human rights violation. It should be noted here that the lack of response by the concerned government to the communication does not necessarily imply a lack of impact. At times, measures are taken in the absence of an official reply to the special procedures. A rather interesting example is the development which followed the letters of concern of the Special Rapporteur on the right to food addressed to Turkey and other States funding the building of a dam which could have displaced and impoverished more than 50,000 Kurdish people and flooded the 10,000-year-old town of Hasankeyf. ${ }^{66}$ In 2008, the German, Austrian and Swiss governments pulled out of the project concerning the building of the Ilisu Dam and Hydro- 
Electric Power Plant Project on the River Tigris, since the Turkish authorities had not solved the social and environmental problems. While it is difficult to show a direct causal link between the Special Rapporteur's communication and this decision, anecdotal evidence shows that the Special Rapporteur's involvement was an additional point of pressure on an already complicated diplomatic situation.

A second important type of communication is that addressed to non-State actors. In order to respond to the increasing recognition that human rights violations can be committed by entities other than States, the ESC rights mandate holders have sought to address this through adapting their existing working methods. Either because the source of violations stem from the non-state actors themselves or because these actors contribute to human rights abuses through their actions or inaction, mandate-holders on ESC rights have addressed an increasing number of communications to corporations and international organisations. Such an endeavour is particularly suitable in cases when the concerned State is unwilling or incapable of redressing the situation. The Addendum of the 2010 report of the Special Rapporteur on the right to food contains communications sent and received from 18 companies and testifies to the level of sophistication that such communications have reached. ${ }^{67}$ International financial institutions ${ }^{68}$ and other international organizations ${ }^{69}$ including hybrid actors such as the Global Fund to Fight AIDS, Tuberculosis and Malaria ${ }^{70}$ have also received and replied to communications from various special procedures regarding matters related to ESC rights. The experience of the special procedures with communications to non-state actors suggests that these actors focused in their replies on facts: generally, and most notably, they did not challenge the existence of an obligation in relation to the ESC rights applicable to them.

\section{Publicity and media}

In the absence of any response to communications, and when finding a remedy is an urgent matter, special procedures have made use of naming-and-shaming techniques via appeal to the media. In the case of the North Korean 'refugees from hunger', a solution was found after the submission of an urgent appeal, a subsequent press release and the presentation of the issue before the General Assembly. Jean Ziegler, the then Special Rapporteur on the right to food, informed the press in 2004 that people pushed by the food crisis to escape hunger by crossing the border into China were forcefully repatriated by China and faced severe punishment in the Democratic People's Republic of Korea. ${ }^{71}$ As a result of the Special Rapporteur's continued prompting, and after a mediation of the UN Secretary General, Japan and South Korea proposed to receive the 'refugees'.

At times, special procedures have tried to catch the public eye and have issued (joint) press releases on critical situations timed to coincide with international conferences. Press conference have also been organized before, during or after a country visit and have been useful for mobilizing civil society -the local vector that can monitor most effectively States' obligations and thus contribute significantly to the realization of ESC rights.

\section{Increasing the impact of the special procedures protection work}

Several aspects require improvement in order to increase the impact of the protection work of the special procedures on ESC rights, including the need to better link communications to thematic reports and country missions to address violations from a more holistic point of view and thus address the root causes of the violations, as well as assure that victims find a remedy.

There is also a need to systematize the relationship with victims and NGOs in relation to the kind of communications received, particularly in order to diversify the topics and 
sources of information. It might become problematic, in terms of the perceived impartiality of the expert, if most of his/her communications are based on the information given by one NGO or if they focus with predilection on one particular subject (even if only because this has been the only subject of communications received). It also limits the opportunity to use communications as a means of further clarifying and promoting the importance of particular aspects of ESC rights if the special procedures do not receive a wide variety of types of communications to address. While the access to qualitative information and means of dissemination is facilitated by the existence of international NGOs working on ESC rights (in particular those focusing on specific rights, such as FIAN and COHRE), ${ }^{72}$ more could be done to reach out to other actors. In the context of an acute lack of resources - financial, personnel and time - there is a great need for a well-functioning, systematized partnership with many different actors, such as UN agencies, civil society organizations, national human rights institutions and academic institutions. A recent report published in the context of the five-year review of the Human Rights Council points to this need for greater expertise in the Council in particular in relation to special procedures, showing how better use can be made of both internal and external expertise and how this can benefit the quality and quantity of the Council's work and of its special procedures. ${ }^{73}$

Scarce resources also create difficulty in the follow-up process, once a response has been received. At the same time, it is important to systematize timeliness and reaction when there is no reply by States, given the empirical evidence showing that only few States respond during the first three months after the communication, but much more do so in a period of one year. Also, a link needs to be established with the remedies used at the national and regional levels. Special procedures have contributed and can increase their contribution to human rights protection through court cases. ${ }^{74}$

It is important to note here, more generally, that the lack of resources is an overarching problem of the special procedures protection system. Nevertheless, ESC rights mandate-holders appear to be most affected, also because there continues to exist an inequality of staff at the OHCHR, favouring CP rights special procedures over the ESC rights ones. In this context, some experts - e.g. Katarina Tomasevski, Paul Hunt, Jean Ziegler, Olivier de Schutter - have created or made use of independent academic/research projects to support their mandates (although, again, this is not unique to the ESC rights special procedures). However, this is not a viable solution for all mandate holders or the system as a whole, as the issue of unequal opportunities for experts from the Global South remains current.

Despite progress in recent years, attested by the growing number of communication received, it appears that a lack of knowledge among individuals and NGOs persists about the special procedures' communications mechanisms. At the same time, the existing expectations of some of those individuals and actors utilizing the communications channel are mismatched with the capacity of special procedures, both in terms of available resources and their actual institutional capacity to obtain a remedy for victims. Thus, it becomes obvious that improvements are needed in disseminating information about the special procedures protection mechanisms, while ensuring that these mechanisms are neither idealized nor misused.

\section{Country missions}

Country visits or missions by ESC rights special procedures are an important facet of the UN human rights monitoring system and an essential tool for improving the implementation of ESC rights on the ground. Over the years, visits have been made to diverse countries, in the global North and South, in conflict and post-conflict zones, in countries with strong or weak 
UN presence, and with a thriving or weak civil society. Missions by individual special procedures and joint missions with two or more special procedures have been performed. Beyond the efficiency in terms of resources, joint missions also make a significant conceptual contribution by underlining the indivisibility of human rights.

The usual procedure for undertaking a country visit starts with an invitation from a government - some States have issued standing invitations ${ }^{75}$ - or a request by the Human Rights Council. The procedure ends with the presentation of the mission report to the Council by the mandate-holder. The independence of the special procedure during these visits is essential, not only for the validity of the information gathered, but also in order to be able to influence and mobilize various actors. Special procedures mandate-holders have refused invitations if a sufficient degree of independence has not been agreed to prior to the visit.

\section{Common features}

Country visits by ESC rights special procedures reveal a number of common features. The international experts usually commence with an evaluation of steps taken by the government, ie. the laws, policies and programs, which address the implementation and realization of the ESC right(s) in question. A focus on the most vulnerable and marginalized groups and individuals is also common. The special procedures also address relevant variants of the "4As scheme' and the States' obligations to respect, protect and fulfil ESC rights. Meetings with various stakeholders are held, including national and local authorities, civil society organizations and communities. Victims of violations of ESC rights are visited and their testimonies heard. The recommendations then issued by the mandate-holder usually concern both immediate and structural measures to be taken by the government and/or other actors.

\section{The impact of country missions}

The impact of a mission on the implementation of ESC rights in the visited countries may vary from very important to quasi-null. Experience suggests some modalities to improve the impact.

The relationship with all stakeholders is an important variable, which can considerably influence the impact of a mission. It is thus essential to build well-functional working relations in particular with UN country teams, national human rights institutions, civil society organizations and the media. During the mission of the Special Rapporteur on the right to adequate housing to Peru in $2004,{ }^{76}$ the Government and Peruvian civil society began a dialogue on housing rights issues which continues to this day and has greatly helped improve the situation on the ground. Prior to, during, and after the mission of the Special Rapporteur on the right to food in Guatemala in $2005,{ }^{77}$ different actors - the Government, FAO and NGOs - coordinated their work and actions. The effect of this coordination was that national legislation and policies were shaped to reflect international standards on the right to food, the government acted upon the recommendations of the Special Rapporteur, and civil society monitored the implementation of these recommendations. ${ }^{78}$

What becomes clear from the above examples is that there is a need for special procedures to build support among the local communities and civil society organizations for their initiatives, so as to develop a critical mass capable of taking the recommendations further and creating a form of 'shelf life'.

The presence of the special procedures in a country can function as a catalytic element in places where individuals, groups and organizations are already working on the promotion and protection of ESC rights. ${ }^{79}$ The mission thus reinforces their work and assists civil society organizations which in most cases become vital actors in the follow-up process of monitoring 
the implementation of the special procedures' recommendations. At times, through their presence and actions in a country, special procedures can legitimize the work of individuals or organizations which were previously delegitimized or even criminalized. There is also an aspect of human solidarity at play, when marginalized or vulnerable groups feel that they are recognized as human rights victims. At the same time, it is highly difficult, if not impossible, for the country mission to achieve any impact in the absence of key stakeholders working on ESC rights in a country.

Communication and information sharing among the special procedures themselves and other monitoring bodies is also vital for the success of a mission. In a context of scarce resources an integration of the available information is paramount.

Follow-up processes represent another important aspect, vital to increasing the impact of a country visit and assuring that recommendations are being implemented. Such processes include: follow-up reports of the special procedures based on information submitted by different actors; ${ }^{80}$ follow-up missions undertaken by the expert him/herself; ${ }^{81}$ monitoring the implementation of the special procedures recommendations by field officers of the OHCHR when present in the country - and/or other members of the UN country teams; monitoring by national human rights institutions (NHRIs) and civil society organizations. ${ }^{82}$ NHRIs have a key role to play, as well as civil society organizations. More recently, the Universal Periodic Review (UPR) mechanism of the Human Rights Council is also helping raising attention regarding the need for States to implement recommendations from country missions' reports, particularly through the inclusion of such information in one of the foundational inputs to the UPR.

Impact appears to improve when the legal framework developed by the special procedures are used in the country missions and vice versa. ${ }^{83}$ Indeed, concrete guidelines make it easier for governments to identify what needs to be changed and how, while problems and opportunities encountered during the implementation process can feed back to improve the instrument.

The mission of the Independent Expert on foreign debt, Cephas Lumina, to Ecuador demonstrates how country visits can have an impact well beyond the intended national borders. The visit of the mandate-holder was followed by an interest in the region to create a regional bank, independent of international institutions. Another example is the mission on the right to food in Guatemala, followed by a regional conference on fighting hunger organized in Guatemala City.

As for examples of concrete impacts following country missions, several recommendations issued by special rapporteurs after their missions were directly implemented by the relevant governments, such as: the recommendations of the Special Rapporteur on the right to food in relation to Guatemala; the recommendations on the right to housing implemented in Peru, Mexico, and Kenya; the recommendation on the right to education referring to fiscal equity in the New York state school system support and the introduction of human rights trainings for health professionals in Sweden; the legislative changes prompted by the presence of Paul Hunt as a guest speaker in the Swedish Parliament; and changes concerning the right to health with the help of the WHO national office in Uganda.

In the early days of operation of the ESC rights mandate-holders, Theo van Boven argued that economic rights mandates were not particularly suitable for fact-finding due to their structural character. ${ }^{84}$ In hindsight it would appear that economic, social and cultural rights mandate-holders have been adequately able to perform fact-finding and country missions. If the legal frameworks developed are clear, the goals of the mission set, contacts and working relations with all stakeholders established, and indeed if they are benefitting from 'a window of opportunity', country visits by special rapporteurs and independent experts 
can be successful and can contribute to the realization of ESC rights nationally and internationally.

Moreover, some ESC rights mandate-holders have innovated the special procedures toolbox by undertaking visits to international organizations and transnational corporations in addition to country missions. ESC rights special procedures have thus shown the importance of adapting their working methods to a globalized world in which non-state actors (not only States) ought to be addressed and bound by human rights obligations so as to assure protection of the individuals' rights. Paul Hunt undertook several innovative missions to the World Trade Organization, the International Monetary Fund and the World Bank, as well as to the pharmaceutical company GlakoSmithKline. Following each of these missions he produced reports that detailed the framework of obligations of these entities. ${ }^{85}$ Olivier de Schutter has also visited the World Trade Organization (WTO) in 2009 and put forward a series of proposals in an attempt to reconcile trade liberalisation with the right to food. ${ }^{86}$

\section{Conclusion}

The special procedures system has developed in leaps and bounds during the last decade. From the establishment of the first ESC rights specific mandate-holder in 1998, to the latest independent experts appointed in this area (the Independent Expert on the right to water and sanitation, appointed in 2008, and the Independent Expert in the field of cultural rights, appointed in 2009), the mandate-holders have made important contributions to defining the normative content of ESC rights and the correlative States obligations, as well as to the development of interpretive instruments. Despite their limited resources, special procedures have contributed to the enhanced understanding of the rights, and perhaps more importantly, the implementation of these rights on the ground. By not shying away from forging a human rights-based approach to emerging issues, and through engaging with the media and utilizing the naming-and-shaming facilities available to them, ESC rights special procedures have prompted governments and non-state actors to better prioritize ESC rights at all levels. They have also used their mandates to provide a protection role, taking up communications with duty-bearers when rights are violated or are at risk of violation. The lack of challenge to the special procedures in employing these working methods shows a general acceptance of the value of their work. Building on the three main outputs of special procedures - thematic reports, communications and country visit reports - governments, international organisations, national human rights institutions, civil society, and individuals, in all regions of the world, have been able to further the global understanding and local implementation of ESC rights.

While the examples set out above highlight some of the key ways in which special procedures have had a positive impact, they also highlight the limits and limitations of special procedures (many of which are not restricted to the domain of ESC rights). A lack of resources and the need for stakeholder buy-in are key, although in recent times efforts to combine forces between special procedures appears to be successful in addressing these deficiencies while simultaneously prompting a reinforcement of the indivisibility, interrelatedness and inter-dependence of all human rights.

Yet many limitations remain. For instance, the special procedure system, being as it is a mechanism mandated by an intergovernmental body, is heavily reliant upon the cooperation of key stakeholders, in particular governments. Without invitations from governments, country visits are not possible; without government willingness to respond to communications and to implement recommendations, such communications and recommendations have limited relevance. Further, while it has been shown above that it is possible for the special procedures to initiate or participate in the improvement of concrete situations, national laws or policies and programs, it is extremely difficult for them to initiate changes in the structures of 
oppression, which are perpetuating exclusion and discrimination against the most vulnerable groups in almost all countries.

However, the progress that has been made since the creation of the first ESC rights mandate in the development of ESC rights in international law and their implementation shows the enormous potential of these mechanisms. In the context of current and upcoming projects reviewing the role of such mechanisms, in particular the review of the Human Rights Council in 2011, stakeholders should be mindful to consider the progress that has been made over a relatively short time, and the need to continue to remove impediments to enhancing the effectiveness of these very special procedures.

\footnotetext{
1 See OHCHR, 'Special Procedures assumed by the Human Rights Council, Thematic Mandates', http://www2.ohchr.org/english/bodies/chr/special/themes.htm (accessed 20 June 2010).

${ }^{2}$ Several factors contributed to redressing the inferiority of ESC rights within the UN system of rights, such as the establishment of the Committee on Economic, Social and Cultural Rights and its important work in interpreting the provisions of the International Convention on Economic, Social and Cultural Rights (ICESCR), the increased adjudication of cases involving ESC rights at national and regional level, the work of local, national and international NGOs on ESC rights, and not least of all a growing recognition that poverty, development, conflict and rights are interrelated, as reflected in the Millennium Development Declaration.

${ }^{3}$ Hereafter, the Independent Expert on extreme poverty.

${ }^{4}$ Hereafter, the Special Rapporteur on the right to adequate housing.

${ }^{5}$ Hereafter, the Independent Expert on foreign debt.

${ }^{6}$ Hereafter, the Special Rapporteur on the right to health.

${ }^{7}$ Hereafter, the Independent Expert on water and sanitation.

${ }^{8}$ See, for example, Report of the Independent Expert on the Situation of Human Rights in Haiti, Michel Forst, UN Doc A/HRC/11/5, 26 March 2009, paras 81-86; Report of the Special Rapporteur of the Commission on Human Rights, John Dugard, on the situation of human rights in the Palestinian territories occupied since 1967, UN Doc E/CN.4/2006/29, 17 January 2006, para. 37.

${ }^{9}$ Notably, the following works deal with special procedures: Philip Alston, 'The Commission on Human Rights', in The United Nations and Human Rights, ed. Philip Alston, (Oxford: Clarendon Press, 1992):126-210; Jeroen Gutter, 'Special Procedures and the Human Rights Council: Achievements and Challenges Ahead', Human Rights Law Review 7, no.1 (2007): 93-107; Oliver Hoehne, 'Special Procedures and the New Human Rights Council's need for Strategic Positioning', Essex Human Rights Review 4, no.1 (2007): 48-64; Ingrid Nifosi, The UN Special Procedures in the Field of Human Rights (Antwerpen, Oxford: Intersentia, 2005); Bertrand G. Ramcharan, The Protection Roles of UN Human Rights Special Procedures (The Hague: Martinus Nijhoff, 2009); Nigel Rodley, 'United Nations Human Rights Treaty Bodies and Special Procedures of the Commission on Human Rights: Complementarity or Competition?', Human Rights Quarterly 25 (2003): 882908. A series of working papers have been prepared by the OHCHR for the review of the special procedures during the transition from the Commission on Human Rights to the Human Rights Council, see http://www2.ohchr.org/english/bodies/chr/special/annual meetings/13th.htm. A project on the role of the special procedures has also been initiated by the Brookings Institution, although the final report was not available at the time this article was finalized.

${ }^{10}$ A number of the ideas in this paper were initially discussed at an 'Expert Meeting on the Impact of the ESC Rights Special Procedures on Human Rights' convened in June 2009 by the Geneva Academy of International Humanitarian Law and Human Rights and sponsored by the Friedrich Ebert Foundation (FES) in Geneva. The meeting benefitted from the input of current and former ESC rights special rapporteurs and independent experts, as well as a number of their former and current advisors and researchers from both OHCHR and from independent research projects.

11 Annual report of the Special Rapporteur on the right to education, Katarina Tomasevski, UN Doc E/CN.4/1999/49, 13 January 1999, paras 51-74; Annual report of the Special Rapporteur on the right to education, Katarina Tomasevski, UN Doc. E/CN.4/2000/6, 1 February 2000, paras 32-65; Annual report of the Special Rapporteur on the right to education, Katarina Tomasevski, UN Doc. E/CN.4/2001/52, 11 January 2001,
} 
paras 64-77; Annual report of the Special Rapporteur on the right to education, Katarina Tomasevski, UN Doc. E/CN.4/2002/60, 7 January 2002, paras 22-45.

${ }^{12}$ Katarina Tomasevski, Education Denied: Costs and Remedies (London: Zed Books, 2003$), 51$.

${ }^{13}$ Ibid, 51-52. Convention of the Right of the Child, adopted on 20 November 1989, entered into force 2 September 1990.

${ }^{14}$ See Committee on Economic, Social and Cultural Rights, General Comment No. 13: The right to education (Art.13), UN Doc. E/C.12/1999/10, 8 December 1999, para. 6. See also Committee on Economic, Social and Cultural Rights, General Comment No. 12: Right to adequate food, UN Doc. E/C.12/1999/5, 12 May 1999, paras 6-13; Committee on Economic, Social and Cultural Rights, General Comment No. 15: The right to water, UN Doc. E/C.12/2002/11, 20 January 2003, para. 12. See also the overview in the Report of the independent expert on the issue of human rights obligations related to access to safe drinking water and sanitation, Catarina de Albuquerque, UN Doc. A/HRC/12/24, 1 July 2009, paras 13-59. (Hereafter, De Albuquerque, HRC Report 2009).

${ }^{15}$ For a recent example of the adaptation of the '4As' scheme, see De Albuquerque, HRC Report 2009paras 6980.

${ }^{16}$ See World Health Organization, The Global Water Supply and Sanitation Assessment 2000, Geneva, 2000; World Health Organization/UNICEF, Progress on Drinking-water and Sanitation: Special Focus on Sanitation, Geneva, 2008.

${ }^{17}$ Elements related to sanitation arose in the work of the Committee on ESC Rights as part of other ESC rights, however there is no comprehensive analysis of sanitation. For example, General Comment 15 on the right to water treats the topic of sanitation only marginally. See CESCR, General Comment No. 15. See also mention of sanitation in the comment on the right to housing: Committee on Economic, Social and Cultural Rights, General Comment No. 4: Right to adequate housing, 13 December 1991.

${ }^{18}$ De Albuquerque, HRC Report 2009.

${ }^{19}$ Ibid, para. 63.

${ }^{20}$ Ibid, para. 60 .

${ }^{21}$ The framework of States' obligations to respect, protect and fulfill, was firstly developed within the UN system in respect to the right to food by Asbjørn Eide in the early 1990s and consecutively applied by the Committee on ESC Rights and UN special rapporteurs on other economic, social and cultural rights. See Updated study on the right to food, submitted by Mr. Asbjørn Eide in accordance with Sub-Commission decision 1998/106, 28 June 1992, UN Doc. E/CN.4/Sub.2/1999/12. See also Magdalena Sepulveda, The Nature of the Obligations under the International Covenant on Economic, Social and Cultural Rights, (Antwerpen, Oxford, New York: Intersentia, 2003), $209-247$.

${ }^{22}$ Only when people are unable to access sanitation for reasons beyond their control, such as in the case of extreme poverty or natural disasters, is the State required to actually provide sanitation services: De Albuquerque, HRC Report 2009, paras 67-68.

${ }^{23}$ UN GA, 'The human right to water and sanitation', UN Doc. A/64/L.63/Rev.1, 26 July 2010; see also "General Assembly adopts resolution recognizing access to clean water, sanitation as human right, by recorded vote of 122 in favour, none against, 41 abstentions", Department of Public Information, 28 July 2010. UN Human Rights Council, 'Human rights and access to safe drinking water and sanitation', UN Doc. A/HRC/15/L.14, 30 September 2010. The resolution of the Human Rights Council affirming the human right to safe drinking water and sanitation has been adopted by consensus.

${ }^{24}$ Report of the Special Rapporteur on the right to food, Jean Ziegler, UN Doc. E/CN.4/2005/47, 24 January 2005, paras 39-40.

${ }^{25} \mathrm{Ibid}$, para. 34 . See also the analysis at paras 44-59.

${ }^{26}$ Report of the Special Rapporteur on the right to food, Olivier De Schutter, UN Doc. A/HRC/10/5/Add.1, 17 February 2009.

${ }^{27}$ Report of the Special Rapporteur on the right of everyone to the enjoyment of the highest attainable standard of physical and mental health, Paul Hunt, UN Doc. A/HRC/4/28/Add.2, 5 March 2008, para. 17.

${ }^{28}$ See, for example, Report of the Special Rapporteur on the right of everyone to the enjoyment of the highest attainable standard of physical and mental health, Paul Hunt, UN Doc. E/CN.4/2004/49/Add.1, 1 March 2004.

${ }_{29}$ Report of the Special Rapporteur on the right of everyone to the enjoyment of the highest attainable standard of physical and mental health, Paul Hunt, UN Doc. A/HRC/4/28/Add.2, 5 March 2008, para. 30.

${ }^{30}$ Report submitted by the Special Rapporteur on the right to education, Vernor Muñoz Villalobos, UN Doc. E/CN.4/2006/45, 8 February 2006.

${ }^{31}$ Report of the Special Rapporteur on the right to education, Vernor Muñoz Villalobos, UN Doc. A/HRC/4/29, 19 February 2007.

${ }^{32}$ Report of the Special Rapporteur on the right to education, Vernor Muñoz Villalobos, UN Doc. A/HRC/11/8, 2 April 2009. 
${ }^{33}$ Report of the Special Rapporteur on the right to food, Jean Ziegler, UN Doc. A/58/330, 28 August 2003.

${ }^{34}$ Report of the Special Rapporteur on the right to food, Jean Ziegler, UN Doc. A/HRC/4/30, 19 January 2007.

${ }^{35}$ Report of the Special Rapporteur on the right to food, Jean Ziegler, UN Doc. A/HRC/4/30/Add.1,18 May 2007.

${ }^{36}$ Report of the Special Rapporteur on adequate housing as a component of the right to an adequate standard of living, Miloon Kothari, UN Doc. E/CN.4/2004/48, 8 March 2004.

${ }^{37}$ Report of the Special Rapporteur on adequate housing as a component of the right to an adequate standard of living, Miloon Kothari, UN Doc. E/CN.4/2005/48, 3 March 2005.

${ }^{38}$ The Voluntary Guidelines to support the progressive realization of the right to adequate food in the context of national food security, FAO, Rome 2005.

${ }^{39}$ Report of the Special Rapporteur on the right to food, Jean Ziegler, UN Doc. A/59/385. 27 September 2004, paras 25-32.

40 The Draft General Guidelines on Foreign Debt and Human Rights, http://www2.ohchr.org/english/issues/development/debt/DraftGuidelines.htm (accessed 10 June 2010).

${ }^{41}$ The Draft Guiding Principles on Extreme Poverty and Human Rights: The Rights of the Poor are available online together with background information on the drafting, the consultation process and the current efforts to 'improve' the Guidelines at http://www2.ohchr.org/english/issues/poverty/consultation/index.htm (accessed 10 June 2010).

42 Human Rights Guidelines for Pharmaceutical Companies in relation to Access to Medicines, http://www2.ohchr.org/english/issues/health/right// (accessed 10 June 2010).

${ }^{43}$ The remark was made in a reply by GlaxoSmithKline to Paul Hunt's report on his mission to the company, available at http://www.gsk.com/responsibility/downloads/GlaxoSmithKline-Statement-in-response-to-the-PaulHunt-Report-on-GSK.pdf (accessed 10 June 2010). In the report, the Special Rapporteur applies the Guidelines in part, see Report of the Special Rapporteur on the right of everyone to the enjoyment of the highest attainable standard of health, Paul Hunt, UN Doc. A/HRC/11/12/Add.2, 18 May 2009.

44 'Right-to-Health Responsibilities of Pharmaceutical Companies', The Lancet 373 (2009), 1998.

${ }^{45}$ Report of the Special Rapporteur on adequate housing as a component of the right to an adequate standard of living, Miloon Kothari, UN Doc. A/HRC/4/18, 5 February 2007. See also Committee on Economic, Social and Cultural Rights, General Comment No. 7: Right to adequate housing: forced evictions, UN Doc.13/12/91, 20 May 1997.

${ }^{46}$ Report of the Special Rapporteur on the right to food, Olivier De Schutter, UN Doc. A/HRC/13/33/Add.2, 28 December 2009.

${ }^{47}$ The Committee on Economic, Social and Cultural Rights has used the Voluntary Guidelines to support the progressive realization of the right to adequate food in the context of national food security in its concluding observations to States parties reports under the ICESCR. See, for example, its concluding observations to Zambia, UN Doc. E/C.12/1/Add.106, 23 June 2005. It also pointed to the Basic Principles and Guidelines on Forced Evictions and Displacement in some of its concluding observations. See, for example, its concluding observations to Cambodia, UN Doc. E/C.12/KHM/CO/1, 12 June 2009.

${ }^{48}$ For example, the Basic Principles and Guidelines on Forced Evictions and Displacement were used in a case before the Constitutional Court of South Africa. See Constitutional Court, Occupiers of 51 Olivia Road Berea Township and 197 Main Street Johannesburg $v$ City of Johannesburg and Others, Amici curiae by the Community Law Centre (UWC) and COHRE, CCT24/07, 2006, para. 63.

${ }^{49}$ To give just two examples, the Basic Principles and Guidelines on Forced Evictions and Displacement are being employed by the Habitat International Coalition and national offices of the OHCHR, while the Voluntary Guidelines to support the progressive realization of the right to adequate food in the context of national food security are used by FIAN and the FAO national offices.

${ }^{50}$ See FAO, Right to Food: Lessons learned in Brazil, FAO, 2007. See also CIIDH, Mision Guatemala... combater el hambre. Informe de Seguimiento a las Recomendaciones del Relator Especial sobre el Derecho a la Alimentación par Guatemala, Jean Ziegler, CIIDH, October 2007, http://www.ciidh.org/publi/desca/pdf/MisionGuatemala.pdf (accessed 10 June 2010).

${ }^{51}$ Enhancing and Strengthening the Effectiveness of the Special Procedures of the Commission on Human Rights, OHCHR Background Paper 2: Working Methods of Mandate-Holders, CHR Dec. 2005/113, section B. Ramcharan proposes the following classification: prevention, urgent action, and appeals; containment and mitigation: the transmittal of complaints to government and visits on the spot; fact-finding, recommendations, and follow-up; remedies; advocacy for protection. See Ramcharan, The Protection Roles of UN Human Rights Special Procedures.

${ }^{52}$ Report of the Special Rapporteur on adequate housing as a component of the right to an adequate standard of living, and on the right to non-discrimination in this context, UN Doc. A/64/255, 6 August 2009.

${ }^{53}$ UNCCD, Human Rights and Desertification: Exploring the Complementarity of International Human Rights 
Law and the United Nations Convention to Combat Desertification, Geneva, 2008.

${ }^{54}$ The declaration and other documents on climate change produced by the Special Rapporteur can be found at http://www.srfood.org/index.php/en/component/content/article/1-latest-news/471-climate-change-policies-mustbe-rooted-in-human-rights-principles (accessed 20 June 2010).

${ }_{55}$ Report of the Special Rapporteur on the right to food, Olivier De Schutter, UN Doc. A/HRC/9/23, 8 September 2008; Report of the Special Rapporteur on the right to food, Olivier De Schutter, UN Doc. A/HRC/12/31, 21 July 2009.

56 'Background Note: Analysis of the Special Rapporteur on the Global Good Crisis', New York, 2 May 2008; Statement of the Special Rapporteur on the right to food to the Human Rights Council, made at its 7th Special Session, held on 22 May 2008, Geneva; Analysis by the Special Rapporteur on the right to food of the Comprehensive Framework for Action, adopted by the United Nations High-Level Task Force on Food Security, 23 June 2008.

${ }^{57}$ See, for instance, the Closing speech of Secretary General Ban Ki-Moon to the High Level Meeting on Food Security For All, Madrid, 27 January 2009 and the Declaration of the World Food Security Summit, Rome, November 2009.

${ }^{58}$ Report of the Special Rapporteur on adequate housing as a component of the right to an adequate standard of living, Miloon Kothari, UN Doc. E/CN.4/2003/5/Add.1, 12 June 2002.

${ }^{59}$ Report of the Special Rapporteur on the right to education, Vernor Muñoz, UN Doc. A/HRC/8/10, 20 May 2008.

${ }^{60}$ Report of the Special Rapporteur on the right to food, Jean Ziegler, UN Doc. E/CN.4/2002/58, 10 January 2002.

${ }^{61}$ Report of the Special Rapporteur on the right to food, Jean Ziegler, UN Doc. E/CN.4/2004/10/Add.2, 31 October 2003.

${ }^{62}$ Report of the Special Rapporteur on the right to food, Jean Ziegler, UN Doc. A/HRC/2/8, 29 September 2006.

${ }^{63}$ Legal Consequences of the Construction of a Wall in the Occupied Palestinian Territory, Advisory Opinion, ICJ Reports 2004, para. 133.

${ }^{64}$ Code of Conduct, art. 9.

${ }^{65}$ This practice has been sanctioned by the Code of Conduct for Special Procedures Mandate-holders adopted by the Human Rights Council in 2007. See in particular, Code of Conduct, Art. 10.

${ }^{66}$ Report of the Special Rapporteur on the right to food, Jean Ziegler, UN Doc. A/HRC/4/30/Add.1, 18 May 2007, paras 10, 28, 64 and 66 .

${ }^{67}$ Report of the Special Rapporteur on the right to food, Olivier De Schutter, UN Doc. A/HRC/13/33/Add.1, 26 February 2010, paras 72-81.

${ }^{68}$ See, for example, the correspondence between the Special Rapporteur on the right to food and the World Bank. Report of the Special Rapporteur on the right to food, Jean Ziegler, UN Doc. A/HRC/4/30/Add.1, 18 May 2007; Report of the Special Rapporteur on the right to food, Jean Ziegler, UN Doc. A/HRC/7/5/Add.1, 29 February 2008.

${ }^{69}$ See, for example, Paul Hunt's urgent appeal, sent together with other special procedures, to the United Nations Interim Administration Mission in Kosovo. See Report of the Special Rapporteur on the right of everyone to the enjoyment of the highest attainable standard of physical and mental health, Paul Hunt, UN Doc. A/HRC/7/11/Add.1, 4 March 2008.

${ }^{70}$ Report of the Special Rapporteur on the right of everyone to the enjoyment of the highest attainable standard of physical and mental health, Anand Grover, UN Doc. A/HRC/11/12/Add.1, 18 May 2009.

${ }^{71}$ Report of the Special Rapporteur on the right to food, Jean Ziegler, UN Doc. A/59/385, 27 September 2004.

${ }^{72}$ For example, the Centre on Housing Rights and Evictions (COHRE) is an NGO that works on the right to housing and information provided by it has been used by the Special Rapporteur on the right to adequate housing. FIAN International specializes on the right to food and provided information useful to the Special Rapporteur on the right to food.

${ }^{73}$ Kamelia Kemileva, Benjamin Lee, Claire Mahon and Chris Sidoti, Expertise in the Human Rights Council, A policy paper prepared under the auspices of the Geneva Academy of International Humanitarian Law and Human Rights, June 2010, available at http://www.adh-geneve.ch/pdfs/expertise.pdf (last accessed 13 October 2010).

${ }^{74}$ See, for instance, the affidavit of the Special Rapporteur on the right to food to the High Court of the Cape of Good Hope in respect to right to food of traditional fishers communities, High Court of South Africa (Cape of Good Hope Provincial Division), Kenneth George and Others v. Minister of Environmental Affairs \& Tourism, Case No. EC 1/2005, Supporting Affidavit by Jean Ziegler.

${ }^{75}$ As of 10 February 2010, 67 States had extended a standing invitation to special procedures. See the list of these States at http://www2.ohchr.org/english/bodies/chr/special/invitations.htm (last accessed 10 June 2010). 
${ }^{76}$ See Report of the Special Rapporteur on adequate housing as a component of the right to an adequate standard of living, Miloon Kothari, UN Doc. E/CN.4/2004/48/Add.1, 11 February 2004.

${ }^{77}$ See Report of the Special Rapporteur on the right to food, Jean Ziegler, UN Doc. E/CN.4/2006/44/Add.1,18 January 2006.

${ }^{78}$ See CIIDH, Mision Guatemala.

${ }^{79}$ See the reports of Jean Ziegler on his missions to India and Bolivia, UN Doc. E/CN.4/2006/44/Add.2,20 March 2006 and UN Doc. A/HRC/7/5/Add.2, 30 January 2008.

${ }^{80}$ See, for example, Report of the Special Rapporteur on adequate housing as a component of the right to an adequate standard of living, and on the right to non-discrimination in this context, Raquel Rolnik, UN Doc. A/HRC/13/20/Add.2, 26 February 2010.

${ }^{81}$ An example is the follow-up missions of Olivier de Schutter to Brazil and Guatemala. See Report of the Special Rapporteur on the right to food, Olivier De Schutter, UN doc A/HRC/13/33/Add.6, 19 February 2010; Report of the Special Rapporteur on the right to food, Olivier De Schutter, UN Doc. A/HRC/13/33/Add.4, 26 January 2010.

${ }^{82}$ See CIIDH, Mision Guatemala.

${ }^{83}$ The OHCHR branch in Mexico prepared a guide on the Basic Principles and Guidelines on Forced Evictions and Displacement to coincide with the visit of the Special Rapporteur on the right to housing in 2003.

${ }^{84}$ T. Van Boven, "Political" and "Legal" Control Mechanisms Revisited', in Human Rights and Criminal Justice for the Downtrodden, ed. M. E. Bergsmo, (Leiden: Brill, 2003), 544. See also the discussion in Hoehne, 'Special Procedures and the New Human Rights Council's need for strategic positioning'.

85 Report of the special rapporteur on the right of everyone to the enjoyment of the highest attainable standard of health, Paul Hunt, UN doc. A/HRC/11/12/Add.2, 18 May 2009; Report of the special rapporteur on the right of everyone to the enjoyment of the highest attainable standard of health, Paul Hunt, UN doc. A/HRC/4/28/Add.2, 5 March 2008; Report of the special rapporteur on the right of everyone to the enjoyment of the highest attainable standard of health, Paul Hunt, UN Doc. E/CN.4/2004/49/Add.1, 1 March 2004.

86 Report of the special rapporteur on the right to food, Olivier de Schutter, UN Doc. A/HRC/10/ 5/Add.2, 4 February 2009. 